\title{
Legal Studies Curriculum for Technical Professionals
}

\author{
Martin S. High, Paul E. Rossler \\ Oklahoma State University \\ Stillwater, OK 74063
}

\begin{abstract}
A novel curriculum has been designed involving the legal aspects of engineering as they apply to technology practice. The purpose of the curriculum is two-fold: 1) to make technical

professionals aware of how engineering practice relates to an organization's legal duties and 2) to encourage those professionals to engage in policy debates that shape business regulation and the common law. From an educational perspective, the curriculum is a logical extension of traditional science and engineering education in that it demonstrates the practical and economic importance of applying sound technical skills. More important, it provides business with technologists who recognize the economic value of responsible design practices. Society, in turn, benefits from better, safer products and processes, and from legal systems and processes that better reflect the unique challenges of technology practice.

Introduction

Starting in the mid-to-late 1970s, and continuing to present day, legal issues have intruded upon engineering and technology practice. Despite the increased probability that an engineer will encounter a legal issue in daily practice, (almost) all engineering curricula do not reflect this, choosing instead to emphasize technical skills in engineering electives. While this emphasis is understandable, it unfortunately does not necessarily help an engineer understand, for example, whether her company's design decisions would satisfy the legal system's risk-utility test for products liability. Nor does it help the engineer to know whether the latest process improvement is valuable intellectual property that can be protected. Instruction on those topics does occur in existing science and engineering curricula, but it tends to be done on an ad hoc basis and without the benefit of educational materials.

This paper addresses a novel curriculum that complements the existing technical curriculum and provides a foundation on which a technical professional can identify legal issues among the myriad technical issues confronted in practice. The paper begins with a brief discussion as to why legal studies are helpful to technical professionals. Next, Oklahoma State University's legal study program goals are described, followed by an overview of the curriculum and courses that comprise the Legal Studies Program. Delivery issues are then discussed. The paper concludes with program assessment results to date and general conclusions as to the benefits of this program to our graduates.
\end{abstract}


Why Legal Studies for Technical Professionals?

Ignorance of the law may be no excuse, but it may very well be the standard operating procedure for a great many technical professionals (and their managers). This, however, does not need to be the case. If a practicing technical professional can recognize and address legal issues early in the design or development process, and recognize when to seek the help of a legal professional, then potential legal problems can be addressed in an active, forward-looking, cost effective manner.

Legal study courses offered in colleges of business nationwide do not focus on the needs of technical professionals. Current business legal study courses focus primarily on topics such as corporate forms, contract law, and agency, as well as emerging topics like Sarbane-Oxley (fiduciary duties relative to corporate accounting). In our experience, students who have enrolled in Oklahoma State's legal studies in engineering courses are particularly interested in how legal and legislative systems work relative to technical issues. For example, students are intensely interested in how the intellectual property system works in the U.S. and abroad. They are interested in learning what a patent is, what is involved in obtaining a patent, and how a patent will help them or their company once that patent is secured.

Because of society's interest in safe and effective technologies, many engineers will find themselves working in fields affected by federal administrative law or regulations. Those regulations, promulgated by various federal agencies, are codified in the Code of Federal Regulations or CFR. How to find, read, and interpret those regulations is a skill that many engineers need to possess. More important, when each regulation is being considered for revision or is still in the proposal stage, the federal agency involved allows for citizen comment from both individuals and organizations. Those citizen comments, along with the proposed regulations and agency contact information, are published in the daily Federal Register. Knowing the process by which regulations are proposed and finalized allows technical professionals to participate in that process. That participation, in turn, increases the likelihood that new regulations make sense from the technologist's point-of-view and ill-considered regulations never see the light of day.

\section{Program Goals}

The legal studies curriculum was designed to:

- incorporate instructional materials that prepare students for the ever expanding role of legal issues into science and engineering practice;

- aid the learning of science, technology, engineering and mathematics by placing those disciplines in the context of the legal responsibilities imposed by society;

- address directly the important opportunity and need of educating future technical professionals on the role of the law in technology endeavors; and,

- produce materials that students and practicing professionals find useful in practice.

It is important to note that the program was not designed to develop any significant legal competence in students. In other words, its purpose is not to create poorly trained, want-a-be 
lawyers. Instead, the goal is to introduce a passing familiarity with basic legal concepts so that the technical professional can recognize potential legal issues and problems and take preventative measures to mitigate any difficulties. The curriculum, therefore, allows engineers to explore the legal concerns, associated liabilities, and causes of action that face a practicing technical professional.

Another objective of the program is to expose interested students to the legal profession. Many students who are interested in law as a profession do not enter engineering or scientific curricula because they do not view engineering as relevant to a legal career. This could not be further from the truth. Areas such as intellectual property law (practically) require a technical background. Other areas, such as environmental law, involve highly technical issues that can be aided by a technical background. And the experiences of the authors show that a rigorous technical curriculum more than adequately prepares students for law school; it is actually an asset in the logical reasoning that is required daily in the study and the practice of law.

Curriculum

During the past three years at Oklahoma State University (OSU), four legal studies courses have been offered, and student interest in these elective courses as measured by enrollment has been strong (Table 1). These elective courses are outlined briefly below and then described later in greater detail.

Table 1. Breadth of Student Interest in Legal Studies Program

\begin{tabular}{|c|c|c|c|c|c|}
\hline \multirow[b]{2}{*}{ Discipline } & \multicolumn{4}{|c|}{ Courses } & \multirow[b]{2}{*}{ All } \\
\hline & $\begin{array}{c}4113 \\
\text { Intellect. } \\
\text { Property }\end{array}$ & $\begin{array}{c}4013 \\
\text { Overview } \\
\text { Course }\end{array}$ & $\begin{array}{c}4133 \\
\text { Environ. } \\
\text { Law }\end{array}$ & $\begin{array}{c}4123 \\
\text { Products } \\
\text { Liability }\end{array}$ & \\
\hline Chemical & 5 & 7 & 0 & 2 & 14 \\
\hline Civil & 1 & 3 & 0 & 1 & 5 \\
\hline Electrical & 19 & 6 & 6 & 5 & 36 \\
\hline ETM* & 16 & 8 & 3 & 1 & 28 \\
\hline Industrial & 9 & 16 & 14 & 2 & 41 \\
\hline Mech \& Aero. & 7 & 1 & 1 & 2 & 11 \\
\hline Other & 8 & 1 & 3 & 0 & 12 \\
\hline All & 65 & 42 & 27 & 13 & 147 \\
\hline
\end{tabular}

* Engineering and Technology Management

The first course, ENGR 4013: Law for Technical Professionals, is a broad-based overview and survey course. The course comprises a single semester and covers a variety of legal issues confronting the technical professional: contracts, torts, products liability, product safety, warnings, design defect, patent, trademark and copyright law, licensing concerns, trade agreements, confidentiality, royalty and capital gains, concerns of the sale of intellectual property, trespass, contamination, health concerns, strict liability and toxic torts. This course was taught for the first time during Fall Semester 2002 and student response was exceptional. Since that time, undergraduate and graduate students (both on and off campus) have enrolled in the course and enthusiastically embraced the material. If an engineering student could take only one legal studies course, this would be the course. 
The three remaining courses, ENGR 4113, ENGR 4123, and ENGR 4133, are specific topical courses addressing products liability law, intellectual property law, and environmental law, respectively. These courses include lectures by adjunct faculty particularly experienced in these legal areas. The courses incorporate current statutory and case holdings, experience in the courtroom, and experience representing manufacturers, corporations, state agencies, and individuals who have been involved in litigation pertaining to these topics. In addition, these courses address local, state, federal and international concerns. The intellectual property course, ENGR 4113, addresses the fundamentals of trade secrets, patent law, copyright, and trademarks. The products liability course, ENGR 4123, addresses many concerns common to all engineering disciplines - determining the engineer's responsibility to design safe products or warn the public about inherently unsafe products. And finally, ENGR 4133 surveys the myriad of environmental laws that clearly affect the practice of science and engineering.

To date, all of the topical courses have been offered. The intellectual property course has been taught three times, Fall 2001, Spring 2002, and Spring 2004. The products liability course and the environmental law course were both offered once, with the products liability course again being offered in Spring 2005. With each offering, student enrollment has been strong (roughly 15 to 20 students) and course evaluations have been good (in all cases, above 3.3 on a four point scale).

\section{ENGR 4013: Impact of Law on Engineering Practice}

This course is designed as a general broad-based, overview course. It is billed as being the course to take if a student wishes to take only one course in legal studies in his or her career. While the topics are wide-ranging and introductory in nature, they are specifically related to the practice of technical professionals and include:

- Historical background of the law

- Introduction to the U.S. Court System

- Basic overview of rules of civil procedure in federal and state court systems

- Torts

- Strict liability and products liability

- Real property law

- Intellectual property law

- Environmental law

- Employment law

As mentioned above, the purpose of this course is not to create poorly trained, want-a-be lawyers out of our science and engineering students. Rather, the purpose is to introduce a passing familiarity with basic legal concepts so that the technical professional can recognize potential legal issues and problems and take appropriate preventative measures to mitigate any difficulties.

\section{ENGR 4113: Intellectual Property Law for Technical Professionals}


Technical professionals are in the business of creating intellectual property for themselves or their employers. Some important types of intellectual property cannot be protected under the law, such as methods of effectively dealing with interpersonal issues involving subordinates and peers. This type of intellectual property cannot be protected, but is nonetheless important. The more commonly accepted intellectual property types with which technical professionals deal, such as patentable inventions or copyrightable works, are also extremely important to the technical professional, and students should have clear understanding of the importance of properly protecting their intellectual property. This course provides an overview of the main areas or four forms of intellectual property:

- trade and service marks;

- copyrights;

- patents; and

- trade secrets.

The course begins with an overview of those four forms of intellectual property and the role each plays in our economy. The differences and similarities between the four forms are then explored by studying various cases, statutes, and regulations. Trademark law relies heavily on cases since its underpinnings lie in relatively old and established common law inherited from England. Copyright law and patent law, however, have a rich and evolving body of statutory and regulatory law. Trade secret law is based primarily on state statutes and common law.

Patent law is emphasized over the other forms of intellectual property because patents have such primacy in technology development and because technologists will more often encounter patent protection than the other forms of intellectual property. Course modules explore the types of materials that can be protected (process, machine, manufacture, or composition of matter, or any new and useful improvement thereof), the basic process of patent prosecution, and the process of protecting patentable technology through infringement litigation.

\section{ENGR 4123: Products Liability Law for Technical Professionals}

The practice of engineering and science inevitably involves some risk such as the risk in the day-to-day practice of science and engineering, and in the product of the activities of scientists and engineers. For example, engineers are clearly in the business of designing and building tools for societal use. Sometimes, injuries occur in the use of these products. In order to fully understand the impact that a given design choice will have on the legal responsibilities of the individual or company involved, the engineer should be aware of the principles involved in how injuries, whether economic or personal, affect design choices. The role of injuries does affect design choices, and the more conversant the technical professional is in the area of torts, strict liability, and products liability, the more informed those design choices will be.

\section{ENGR 4133: Environmental Law for Technical Professionals}

There is likely not a more important mass of laws that affect engineering practice than environmental statutes and regulations, and scientific practice is more commonly affected than previously was the case. While much has been made in the popular and trade literature of the 
onerous demands that environmental regulations put on U.S. industry, the U.S. can be proud of the progress made to date in protecting the environment and in the enforcement of environmental regulations. As policy and regulation continue to evolve in this area, scientists and engineers will remain at the leading edge of both the enforcement of environmental regulations and the development of policy.

The modules that comprise this course are designed to educate technical professionals of the history behind environmental regulation, the legal development of those regulations, the application of current laws and regulations, and the outlook on the policy directions that environmental laws are taking. Technical professionals must be aware of their duties under the current environmental regulatory environment. Successful technology is premised on sound environmental planning and implementation, and many technical decisions are based on environmental rules, rather than on economic or technical constraints. Graduating engineers and scientists without a passing knowledge of environmental laws and regulations is like sending a runner to a marathon without shoes (Zola Bud aside). The environmental law course helps provide the necessary background for students to navigate this important aspect of the law.

\section{Delivery}

Unfortunately, curricular materials for these important topics are not currently available. Only one relevant textbook exists, Legal Aspects of Engineering. ${ }^{1}$ The textbook is written as a compromise between the casebook method used in law schools and the more traditional textbook used in technical courses. Although this approach was likely necessary when the book was first published, basic electronic publishing methods can significantly enhance the learning experience of students, and provide instructors with a more efficient and modular approach. There are other legal aspects textbooks that are directed towards engineers, ${ }^{2}$ but these also tend to be extremely superficial in their treatment of the subject matter. Although a cursory treatment is satisfactory, if not necessary, for an outline course, more in-depth treatment is necessary in several topical areas. Law school casebooks are available and have been used in the three topical courses, but are also not well suited to the audience. No law school textbooks are available in electronic format that allow the instructor to pick portions of the material for inclusion in relevant courses.

Where does all the above leave faculty who are interested in providing legal study courses to students but are not at all interested in spending the time and money required to obtain a J.D.? They can begin in much the same way that we did, by making use of the one textbook that exists and then drawing upon legal resources in the local community. University legal staff should be well versed in intellectual property issues and many local attorneys have expertise in products liability and environmental issues. Contacting the local or state chapter of the Bar Association can put one in contact with several knowledgeable attorneys who are willing to share their expertise with students. In addition, law school faculty have in many cases prepared lectures and short courses targeted to laymen in topical areas of interest to technical professionals. In short, if one has the motivation and interest, lack of a J.D. does not stand in the way of delivering high quality, legal studies content to students. 


\section{Performance to Date}

The four courses that comprise the Legal Studies Program directly address a number of ABET EC2000 outcomes:

f. an understanding of professional and ethical responsibility

h. the broad education necessary to understand the impact of engineering solutions in a global and societal context

i. a recognition of the need for, and an ability to engage in life-long learning

j. a knowledge of contemporary issues

Beginning in Spring 2005, formal program assessment will be conducted relative to those outcomes and then tied to subsequent course development and improvement efforts. To date, program assessment has been limited to a survey of our college's "associates," comprised of distinguished engineering alumni (Table 2) and traditional course evaluations (Table 3). Sixty percent of the associates identified legal issues as being extremely important in their career, and all but a small percentage believed that college support of a program involving legal issues was a valuable expenditure of resources.

Table 2. College of Engineering, Architecture and Technology "Associates" Survey Results (Shown in Percentage)

\begin{tabular}{|c|c|c|c|}
\hline \multirow[t]{2}{*}{ 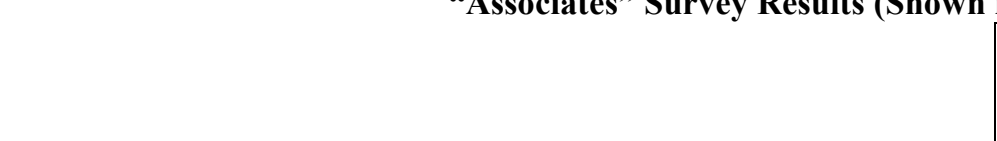 } & \multicolumn{3}{|c|}{ Importance } \\
\hline & $\begin{array}{c}\text { Not } \\
\text { Important }\end{array}$ & $\begin{array}{l}\text { Somewhat } \\
\text { Important }\end{array}$ & $\begin{array}{l}\text { Extremely } \\
\text { Important }\end{array}$ \\
\hline How important have legal issues been in your career? & 5 & 35 & 60 \\
\hline $\begin{array}{l}\text { How favorably would you or your company view a potential } \\
\text { employee's background in legal issues? }\end{array}$ & 5 & 70 & 25 \\
\hline $\begin{array}{l}\text { Do you believe that a program involving legal issues would be a } \\
\text { valuable expenditure of College resources (faculty time and money? }\end{array}$ & 5 & 45 & 50 \\
\hline
\end{tabular}

Table 3. Summary of Student Enrollment and Course Evaluations

\begin{tabular}{|l|c|c|c|c|}
\cline { 2 - 5 } \multicolumn{1}{c|}{} & $\begin{array}{c}\text { 4013 - Overview } \\
\text { Course }\end{array}$ & $\begin{array}{c}4113 \text { - Intellectual } \\
\text { Property Law }\end{array}$ & $\begin{array}{c}4123 \text { - Products } \\
\text { Liability Law }\end{array}$ & $\begin{array}{c}4133 \text { - Environ- } \\
\text { mental Law }\end{array}$ \\
\hline $\begin{array}{l}\text { Number of } \\
\text { Semesters Offered }\end{array}$ & 2 & 3 & 1 & 1 \\
\hline $\begin{array}{l}\text { Total Undergraduate } \\
\text { Student Enrollment }\end{array}$ & 34 & 51 & 12 & 24 \\
\hline $\begin{array}{l}\text { Total Graduate } \\
\text { Student Enrollment }\end{array}$ & 8 & 14 & 1 & 3 \\
\hline $\begin{array}{l}\text { Average Course } \\
\text { Evaluation }\end{array}$ & N/A & 3.50 & 3.33 & 3.55 \\
\hline
\end{tabular}

Conclusion

In much the same way that technical professionals have a place in the practice of law, knowledge of legal issues has a place in the practice of scientists and engineers. As products and processes become more technology-laden and as an increasing number of businesses compete in global 
markets, legal issues will continue to intrude upon the technical professional's daily practice. The curriculum described here is Oklahoma State's attempt to prepare its graduates for the everchanging nature of technical work. From an educational perspective, the curriculum is a logical extension of traditional science and engineering education in that it demonstrates the practical and economic importance of applying sound technical skills. More important, it provides business with technologists who recognize the economic value of responsible design practices. Society, in turn, benefits from better, safer products and processes, and from legal systems and processes that better reflect the unique challenges of technology practice. Last, the program provides yet another career alternative available to technical professionals. Although these materials just scratch the surface of a typical law school program, they can provide sufficient information to a student to determine whether law is an appropriate career alternative.

${ }^{1}$ Richard C. Vaughn, Legal Aspects of Engineering, $6^{\text {th }}$ ed., Kendall-Hunt Publishing Co., Dubuque, IA (1999).

${ }^{2}$ Justin Sweet and Marc M. Schneier, Legal Aspects of Architecture, Engineering, and the Construction Process, $7^{\text {th }}$ ed., Thomson, Toronto (2004). 